\title{
TYPE 2 DIABETES MELLITUS, IMPAIRED GLUCOSE TOLERANCE AND ASSOCIATED COMORBIDITIES IN CHILDREN DURING 2002-2013 IN CHILDREN'S CLINICAL UNIVERSITY HOSPITAL, LATVIA
}

\author{
Jurgita Gailite ${ }^{1,2, \#, ~ A g n e s e ~ M i k i l p a-M i k g e l b a ~}{ }^{1}$, leva Silinaa ${ }^{1}$, Ināra Kirillova ${ }^{1}$, \\ Una Lauga-Tuṇina', Iveta Dzivite-Krišāne ${ }^{1,2}$, and Dace Gardovska ${ }^{1,2}$ \\ ${ }^{1}$ Children's Clinical University Hospital, 45 Vienības g., Rīga, LV-1004, LATVIA \\ 2 Department of Pediatrics, Rīga Stradinš University, 45 Vienības g., Rīga LV-1004, LATVIA \\ \# Corresponding author, jurgita.gailite@bkus.Iv
}

Contributed by Dace Gardovska

\begin{abstract}
The world has seen a rise of type 2 diabetes mellitus in children during the last 20 years. It is proposed that this increase is due to unhealthy eating habits, increasing obesity, especially among teenagers, and better diagnostics. The main risks associated with diabetes are microvascular and macrovascular complications, which can lead to early disability and premature death. The aim of our study was to identify children with type 2 diabetes mellitus or impaired glucose tolerance and investigate associated comorbidities at the time of diagnosis in the Children's Clinical University Hospital in Latvia. A retrospective analysis was performed of all children with type 2 diabetes mellitus or glucose tolerance impairment from 2002 till 2013, who were treated in Children's Endocrinology Centre. According to inclusion criteria, 57 patients were selected of whom 24 (42\%) had type 2 diabetes mellitus and $33(58 \%)$ had impaired glucose tolerance. Body mass index was analysed according to percentile and all patients were found to have excess weight. In children with type 2 diabetes mellitus, all patients had body mass index over the 99th percentile. Arterial hypertension was found in $66.7 \%$ and dyslipidemia in 54.2\% type 2 diabetes mellitus patients. From all type 2 diabetes mellitus patients, $71 \%(n=17)$ were girls and they had statistically significantly higher total cholesterol $(\mathrm{p}=0.02)$ and low-density lipoprotein $(\mathrm{p}=0.003)$ levels. Considering, that girls with type 2 diabetes mellitus have high cardiovascular risk in adulthood, it is very important not only to achieve normal glucose levels early, but also to treat comorbidities, to reduce further microvascular and macrovascular complication risk.
\end{abstract}

Key words: obesity, type 2 diabetes mellitus, impaired glucose tolerance, children.

\section{INTRODUCTION}

Obesity is one of the major health challenges of the 21st century (Phyllis et al., 2005; Alizadeh et al., 2013). Children and adolescents with obesity are at a high risk of developing obesity-related diseases such as cardio-vascular diseases, arterial hypertension ( $\mathrm{AH})$, dyslipidemia, metabolic syndrome (MS), type 2 diabetes mellitus (T2DM), different types of tumours, orthopedic problems, and serious psychological and neurological problems, etc. (Phyllis et al., 2005; Halpern et al., 2010; Alizadeh et al., 2013).

The number of adolescents being diagnosed with T2DM is increasing in America, Europe, Japan and Australia (Phyllis et al., 2005). Increase of T2DM among adolescents is attrib- uted to spread of unhealthy habits, increasing obesity among children and teenagers, and better diagnostics. (Halpern et al., 2010). Unfortunately, no study on T2DM has been done in Latvia in recent years.

Diabetes-related morbidity is caused by microvascular and macrovascular complications, which lead to early disability and premature death (Pinhas-Hamiel et al., 2007). Even at the moment of diagnosing T2DM, patients can already have serious comorbidities, such as arterial hypertension, dyslipidemia, fatty liver etc. (Rosenbloom et al., 2008).

Early detection of T2DM and impaired glucose tolerance (IGT) in adolescents is essential, as early combined therapy can reduce future complications. This group of patients 
needs extensive lifestyle correction — balanced diet, adequate physical activity, lifestyle modification to alter unhealthy habits and weight reduction (Phyllis et al., 2005; Halpern et al., 2010; Alizadeh et al., 2013).

The American Academy of Pediatrics and the American Diabetes Association recommend T2DM screening for adolescents who are overweight and who have two of the following risk factors: a first or second-degree relative with diagnosed type 2 diabetes; those belonging to ethnic populations with increased risk (e.g., African-American, American Indians, Asian and Pacific Islander ethnicities); those with one of the symptoms related to insulin resistance acanthosis nigricans, arterial hypertension, dyslipidemia or polycystic ovary (PCO) syndrome. The screening commences either at 10 years of age or at the onset of puberty (if it is premature), and is repeated every two years. The first examination when starting screening for T2DM in adolescents is measurement of fasting glucose. However, the more accurate, but also more cumbersome examination is the oral glucose tolerance test (OGTT) (Phyllis et al., 2005).

Considering that there have not been any studies looking at T2DM epidemiology in children, our study was aimed to identify children groups with type 2 diabetes mellitus or impaired glucose tolerance and associated comorbidities at the moment of establishing diagnosis. The study was conducted at the Children's Clinical University Hospital in Latvia.

\section{MATERIALS AND METHODS}

Samples, anthropometry and blood tests. A retrospective analysis was performed of all children with type 2 diabetes mellitus or glucose tolerance impairment, who were treated in Children's Endocrinology Centre at the Children's Clinical University Hospital Riga from 2002 till 2013. In total 57 patient cases with impaired glucose tolerance (IGT) or type 2 diabetes mellitus (T2DM) were analysed and they represented only $1.38 \%$ of all patients treated in the Children's Endocrinology centre during that period. All 57 patients had been hospitalised to perform type 2 diabetes mellitus screening using the oral glucose tolerance test (OGTT). After a 12-h overnight fasting, the subjects underwent an OGTT at 08.00 a.m. Glucose was given orally $(1.75 \mathrm{~g} / \mathrm{kg}$ body weight, up to a maximum of $75 \mathrm{~g}$ glucose). Blood samples were drawn after 30, 60, 90, and $120 \mathrm{~min}$. Diagnosis of IGT was made if the blood glucose level after 2 hours was $\geq 7.8-11.0 \mathrm{mmol} / \mathrm{l}$. Diagnosis of T2DM was made if fasting glucose was $\geq 7.0 \mathrm{mmol} / \mathrm{l}$ in venous plasma, or two-hour glucose during OGTT was $\geq 11.1 \mathrm{mmol} / \mathrm{l}$ in venous plasma (Wiegand et al., 2004).

In our descriptive retrospective study, we analysed and summarised patient weight, height, age and blood pressure (BP) rates during hospitalisation. The body mass index (BMI) was calculated using the formula weight $(\mathrm{kg}) /$ height $(\mathrm{m})^{2}$ and evaluated using percentile charts adjusted to age and gender. Baseline test results were obtained for measurement of fasting (venous) thyroid-stimulating hormone
(TSH), total cholesterol (TC), triglycerides (TG), high-density lipoprotein (HDL), low-density lipoprotein (LDL), alanine aminotransferase (ALT), aspartate aminotransferase (AST), glucose and C-peptide.

Blood pressure measurements were assessed according to percentile charts for the relevant age, height and gender. Arterial hypertension was diagnosed if the systolic and/or diastolic blood pressure in the $>95$ percentile in three repeated measurements (Dinesh et al., 2012).

Dyslipidemia was diagnosed using the criteria developed by the National Institutes of Health Heart, Lung and Blood Institute (NHLBI): TC $\geq 5.2 \mathrm{mmol} / \mathrm{l}, \mathrm{TG} \geq 1.5 \mathrm{mmol} / \mathrm{l}, \mathrm{LDL}$ $\geq 3.4 \mathrm{mmol} / \mathrm{l}$, HDL $<1.00 \mathrm{mmol} / \mathrm{l}$ (Yoon, 2014).

The Ethics Committee of the Rīga Stradiňš University approved the study.

Statistical analysis. In our study we used nonparametric statistics descriptive indicators - median, quartiles, interquartile range. Groups were compared with the MannWhitney test. A probability value of less than 0.05 was considered significant. Statistical analysis was performed using IBM SPSS Statistics for Windows, version 22.0.

\section{RESULTS}

In total, there were 57 patients included in the study. There were 24 (7 boys $(29 \%)$ and 17 girls $(71 \%)$ ) diagnosed with type 2 diabetes mellitus, while 33 patients (21 boy (63\%) and 12 girls (37\%)) had impaired glucose tolerance. Median age in the T2DM group was 15 (13.3-17.0 years), in impaired glucose tolerance group - 14 (12.0-16.0). There was no statistically significant age difference between the groups $(p=0.912)$.

All included children had elevated BMI. In the T2DM group, all children had elevated BMI above the $99^{\text {th }}$ percentile and were deemed obese. In the impaired glucose tolerance group, there were four overweight children (BMI above 85 th percentile), while the others had above the $95^{\text {th }}$ percentile.

There was a statistically significant $(p<0.001)$ diastolic blood pressure difference between the groups — in the T2DM group median diastolic blood pressure was 85 $\mathrm{mmHg}$ (75-90 $\mathrm{mmHg}$ ), while in the IGT group - 80 $\mathrm{mmHg}(72-90 \mathrm{mmHg})$. Laboratory parameters revealed a statistically significantly $(p=0.011)$ lower HDL in the T2DM group (Table 1).

Girls with T2DM had significantly higher total cholesterol (median $5.2 \mathrm{mmol} / \mathrm{l}(4.5-5.5)$ ) than girls in the IGT group (median $4.1 \mathrm{mmol} / \mathrm{l}(3.3-4.9))(p=0.02)$. Also, LDL was significantly higher in T2DM girls $(p=0.003)$, than in girls in the IGT group (Table 2).

There was a statistically significant difference between the groups $(p=0.035)$ in BMI of boys - in the T2DM group median BMI in boys was $31.3 \mathrm{~kg} / \mathrm{m}^{2}(30.8-40.4)$, while in 
CHARACTERISTICS OF T2DM AND IGT GROUPS

\begin{tabular}{|c|c|c|c|c|c|}
\hline \multirow[t]{2}{*}{ Variables } & \multicolumn{2}{|c|}{ T2DM group $\mathrm{n}=24$} & \multicolumn{2}{|c|}{ IGT group $n=33$} & \multirow[t]{2}{*}{$p$-value } \\
\hline & median & (interquartile range) & median & (interquartile range) & \\
\hline Age, years & 15.0 & $(13.3-17.0)$ & 14.0 & $(12.0-16.0)$ & 0.912 \\
\hline Height, m & 1.7 & $(1.5-1.7)$ & 1.7 & $(1.5-1.7)$ & 0.141 \\
\hline BMI, kg/m² & 31.2 & $(27.3-38.7)$ & 28.6 & $(24.0-36.4)$ & 0.058 \\
\hline Glucose, mmol/l & 6.1 & $(5.3-6.4)$ & 5.5 & $(5.1-6.0)$ & 0.093 \\
\hline c-peptide, ng/ml & 3.6 & $(2.5-5.1)$ & 2.7 & $(1.5-4.2)$ & 0.780 \\
\hline ALT, U/1 & 26.0 & $(18.0-66.0)$ & 31.0 & $(15.1-49.0)$ & 0.705 \\
\hline AST, U/1 & 21.5 & $(17.0-68.9)$ & 28.0 & $(22.9-36.9)$ & 0.209 \\
\hline $\mathrm{TSH}, \mathrm{mU} / \mathrm{l}$ & 2.0 & $(1.5-3.1)$ & 2.5 & $(1.6-3.9)$ & 0.008 \\
\hline $\mathrm{TC}, \mathrm{mmol} / \mathrm{l}$ & 5.2 & $(4.4-5.6)$ & 4.3 & $(3.4-5.0)$ & 0.654 \\
\hline HDL, mmol/l & 1.1 & $(0.9-1.4)$ & 1.2 & $(1.0-1.3)$ & 0.011 \\
\hline $\mathrm{TG}, \mathrm{mmol} / \mathrm{l}$ & 1.7 & $(1.2-2.5)$ & 1.2 & $(0.8-1.8)$ & 0.515 \\
\hline Systolic BP, mmHg & 140.0 & $(127.5-146.0)$ & 130.0 & (121.5-145.0) & 0.609 \\
\hline Diastolic BP, mmHg & 85.0 & $(75.0-90.0)$ & 80.0 & $(72.0-90.0)$ & 0.001 \\
\hline
\end{tabular}

ANTHROPOMETRIC AND LABORATORY VALUES IN GIRLS WITH T2DM AND IGT

\begin{tabular}{|c|c|c|c|c|c|}
\hline \multirow[t]{2}{*}{ Variables } & \multicolumn{2}{|c|}{ T2DM group $\mathrm{n}=17$} & \multicolumn{2}{|c|}{ IGT group $n=12$} & \multirow[t]{2}{*}{$p$-value } \\
\hline & median & (interquartile range) & median & (interquartile range) & \\
\hline Age, years & 15.0 & $(13.3-17.0)$ & 14.0 & $(13.0-16.5)$ & 0.444 \\
\hline Height, m & 1.7 & $(1.5-1.7)$ & 1.7 & $(1.6-1.7)$ & 0.512 \\
\hline BMI, $\mathrm{kg} / \mathrm{m}^{2}$ & 30.5 & $(27.1-37.5)$ & 34.5 & $(26.9-37.4)$ & 0.680 \\
\hline Glucose, mmol/1 & 5.9 & $(5.1-7.1)$ & 5.4 & $(5.3-6.0)$ & 0.302 \\
\hline c-peptide, $\mathrm{ng} / \mathrm{ml}$ & 3.5 & $(2.2-5.1)$ & 3.0 & $(2.2-3.9)$ & 0.581 \\
\hline $\mathrm{ALT}, \mathrm{U} / 1$ & 21.0 & $(16.5-104.7)$ & 28.8 & $(14.0-51.1)$ & 0.904 \\
\hline AST, U/1 & 21.5 & $(16.5-73.6)$ & 23.9 & $(20.6-35.3)$ & 0.927 \\
\hline $\mathrm{TSH}, \mathrm{mU} / \mathrm{l}$ & 1.7 & $(1.4-3.1)$ & 2.5 & $(1.6-3.1)$ & 0.251 \\
\hline $\mathrm{TC}, \mathrm{mmol} / 1$ & 5.2 & $(4.5-5.5)$ & 4.1 & $(3.3-4.9)$ & 0.02 \\
\hline HDL, mmol/1 & 1.1 & $(0.8-1.4)$ & 1.3 & $(1.2-1.4)$ & 0.211 \\
\hline $\mathrm{TG}, \mathrm{mmol} / 1$ & 1.9 & $(1.2-2.1)$ & 0.9 & $(0.6-1.9)$ & 0.211 \\
\hline Systolic BP, mmHg & 140.0 & $(120.0-145.0)$ & 137.0 & $(120.0-145.0)$ & 1 \\
\hline Diastolic BP, mmHg & 80.0 & $(75.0-90.0)$ & 90.0 & $(75.0-95.0)$ & 0.721 \\
\hline
\end{tabular}

the IGT group - $25.9 \mathrm{~kg} / \mathrm{m}^{2}$ (18.9-35.2). There were no statistically significant differences in other parameters between the groups in boys (Table 3 ).

At the time of diagnosis, arterial hypertension was found in $16(66.7 \%)$ of T2DM patients and $18(54.5 \%)$ patients with IGT. There were no statistically significant differences found between the groups concerning arterial hypertension $(p=0.28)$.

At the time of diagnosis, 13 (54.2\%) T2DM patients and $5(15.2 \%)$ IGT patients had dyslipidemia, and this difference was statistically significant between the groups ( $p=$ $0.03)$.

\section{DISCUSSION}

Numerous studies and observations have been carried out investigating excess weight, impaired glucose tolerance and type 2 diabetes mellitus in children (Eyzaguirre et al., 2009; Huang et al., 2009). There are many modifiable and non-modifiable risk factors for childhood obesity. This is important because prevention of childhood obesity reduces the possibility of developing IGT and T2DM ( Maahs et al., 2008; Huang et al., 2009).

Evidence shows that T2DM in children not only differs from type 1 diabetes, but also from type 2 diabetes in adults. It is characterised by a quick decline in the beta cell secretory rate and earlier development of diabetes complica- 
ANTHROPOMETRIC AND LABORATORY VALUES IN BOYS WITH T2DM AND IGT

\begin{tabular}{|c|c|c|c|c|c|}
\hline \multirow[t]{2}{*}{ Variables } & \multicolumn{2}{|c|}{ T2DM group $\mathrm{n}=7$} & \multicolumn{2}{|c|}{ IGT group $n=21$} & \multirow[t]{2}{*}{$p$-value } \\
\hline & median & (interquartile range) & median & (interquartile range) & \\
\hline Age, years & 15.0 & $(13.0-17.0)$ & 13.0 & $(10.0-16.0)$ & 0.228 \\
\hline Height, $\mathrm{m}$ & 1.7 & $(1.6-1.8)$ & 1.7 & $(1.4-1.7)$ & 0.306 \\
\hline BMI, $\mathrm{kg} / \mathrm{m}^{2}$ & 31.3 & $(30.8-40.4)$ & 25.9 & $(18.9-35.2)$ & 0.035 \\
\hline Glucose, mmol/1 & 6.1 & $(5.3-6.4)$ & 5.5 & $(4.9-6.0)$ & 0.155 \\
\hline c-peptide, ng/ml & 3.6 & $(3.0-5.2)$ & 2.6 & $(1.3-4.4)$ & 0.139 \\
\hline $\mathrm{ALT}, \mathrm{U} / \mathrm{l}$ & 34.0 & $(19.0-37.8)$ & 34.2 & $(15.7-49.0)$ & 1 \\
\hline $\mathrm{AST}, \mathrm{U} / \mathrm{l}$ & 21.5 & $(17.5-65.7)$ & 31.8 & $(24.9-38.8)$ & 0.397 \\
\hline TSH, mU/1 & 2.9 & $(1.8-3.8)$ & 2.6 & $(1.8-3.9)$ & 0.866 \\
\hline $\mathrm{TC}, \mathrm{mmol} / \mathrm{l}$ & 5.2 & $(3.9-5.7)$ & 4.3 & $(3.4-5.1)$ & 0.187 \\
\hline HDL, mmol/l & 1.2 & $(1.0-1.3)$ & 1.1 & $(0.9-1.3)$ & 0.494 \\
\hline $\mathrm{TG}, \mathrm{mmol} / 1$ & 1.6 & $(1.3-2.5)$ & 1.3 & $(1.0-1.7)$ & 0.447 \\
\hline Systolic BP, mmHg & 140.0 & $(135-149.0)$ & 130.0 & $(121.8-147.5)$ & 0.220 \\
\hline Diastolic BP, mmHg & 90.0 & $(75.0-90.0)$ & 80.0 & $(69.8-90.0)$ & 0.423 \\
\hline
\end{tabular}

tions (Copeland et al., 2011).The following risk factors are considered for T2DM in children - obesity, family history of diabetes, female gender and low socioeconomic status. (Copeland et al., 2011).

In our study at the time of hospitalisation all patients were overweight, so IGT/T2DM screening was initiated. Most of the patients with T2DM diagnosis were girls $(71 \%, \mathrm{n}=17)$. In our study we did not analyse other risk factors, such as positive diabetes family history and socioeconomic status.

In young people T2DM is diagnosed more frequently during the second decade of life and the average age of diagnosis is 13.5 , coinciding with the physiological peak of insulin resistance (Ball et al., 2006). In our study median age in patients with T2DM was 15 , which means that diabetes screening in children was performed early enough.

The type 2 diabetes diagnosed in adolescence is more frequently associated with medical conditions other than type 1 diabetes (T1D) (Godoy-Matos et al., 2005; Eppens et al., 2006; Kershnar et al., 2006; Pinhas-Hamiel et al., 2007; Önal et al., 2014). Microvascular complications (retinopathy), nephropathy, peripheral neuropathy and macrovascular complications affect the quality of life as well as long term morbidity and mortality. Many studies have shown that the risk of arterial hypertension and dyslipidemia is much higher in patients with T2DM than in patients with T1DM (Godoy-Matos et al., 2005). A multicentre study in USA showed that arterial hypertension was found in $10-32 \%$ of patients with T2DM and was eight times more likely than in patients with T1DM in the same age group. Isolated or combined dyslipidemia was found in 24-44\% of cases (Kershnar et al., 2006). In our study dyslipidemia was found in $54.2 \%$ and arterial hypertension in $66.7 \%$ of children at $\mathrm{T} 2 \mathrm{DM}$ diagnosis.
This finding is very alarming, because children with T2DM and other cardiovascular risk factors, such as arterial hypertension, have drastically increased cardiovascular and premature death risk. Considering that average cardiovascular disease mortality in Latvia is higher in women $(6 \%)$ than men, more attention has to be directed to girls with excess weight (Štāle et al., 2012). Our study showed significantly higher total cholesterol and low-density lipoprotein levels in girls with T2DM, which is associated with increased cardiovascular disease risk. The treatment should not only focus on normalising glucose levels, but also on controlling comorbidities.

The basic treatment goals for children and adolescents with T2DM are: psychologic and family support therapy, weight reduction; lifestyle corrections — balanced diet and increased physical activity. The next step is achieving normal glucose levels and controlling comorbidities, including hypertension, dyslipidemia and hepatic steatosis (GodoyMatos et al., 2005; Phyllis et al., 2005; Maahs et al., 2008; Huang et al., 2009). This strategy would be especially important to children with impaired glucose tolerance.

Adult studies have shown, that lifestyle corrections are more effective than pharmacotherapy in preventing T2DM in patients with impaired glucose tolerance. Pharmacotherapy is very limited in children with T2DM, and the only approved medication is metformin. Even after the pharmacotherapy is initiated, lifestyle corrections have to be continued to reduce the possibility of complications (Rodbard et al., 2007).

\section{CONCLUSIONS}

This retrospective study showed that at the moment of diagnosis of T2DM, 54.2\% children had dyslipidemia and $66.7 \%$ had arterial hypertension. Most of the T2DM pa- 
tients were girls $71 \%$. Considering, that girls with type 2 diabetes mellitus have high cardiovascular risk in adulthood, it is very important not only to achieve normal glucose levels early, but also to treat comorbidities, to reduce further microvascular and macrovascular complication risk.

\section{REFERENCES}

Alizadeh, Z., Khosravi, S., Borna, S. (2013). Obese and overweight children and adolescents: An algorithmic clinical approach. Iranian J. Pediatrics, 23, 621-631

Ball, G. D., Huang, T. T., Gower, B. A., Cruz, M. L., Shaibi, G. Q., Weigensberg, M. J., Goran, M. I. (2006). Longitudinal changes in insulin sensitivity, insulin secretion, and beta-cell function during puberty. $J$. Pediatr., 148, 16-22.

Copeland, K. C., Zeitler, P., Geffner, M., Guandalini, C., Higgins, J., Hirst, K., Kaufman, F. R., Linder, B., Marcovina, S., McGuigan, P., Pyle, L., Tamborlane, W., Willi, S.; TODAYStudy Group. (2011). Characteristics of adolescents and youth with recent-onset type 2 diabetes: the TODAY cohort at baseline. J. Clin. Endocrinol. Metab., 96, 159-167.

Singh, D., Akingbola, O., Yosypiv, I., El-Dahr, S. (2012). Emergency management of hypertension in children. Int. J. Nephrol., 2012, Article ID 420247, $15 \mathrm{pp}$

Eppens, M. C., Craig, M. E., Cusumano, J., Hing, S., Chan, A. K., Howard, N. J., Silink, M., Donaghue, K. C. (2006). Prevalence of diabetes complications in adolescents with type 2 compared with type 1 diabetes. Diabetes Care, 29, 1300-1306.

Eyzaguirre, F., Mericq, V. (2009). Insulin resistance markers in children. Horm. Res. Paediatr., 71, 65-74.

Godoy-Matos, A., Carraro, L., Vieira, A., Oliveira, J., Guedes, E. P., Mattos, L., Rangel, C., Moreira, R. O., Coutinho, W., Appolinario, J. C. (2005). Treatment of obese adolescents with sibutramine: A randomized, double-blind, controlled study. J. Clin. Endocrinol. Metab., 90, 1460-1465.

Halpern, A., Mancini, M.C., Magalhães, M. E. C., Fisberg, M., Radominski, R., Bertolami, M. C., Bertolami, A., de Melo, M. E., Zanella, M. T., Queiroz, M. S., Nery, M. (2010). Metabolic syndrome, dyslipidemia, hypertension and type 2 diabetes in youth: From diagnosis to treatment. Diabetol. Metab. Syndr., 2, 55.

Huang, R. C., Mori, T. A., Burke, V., Newnham, J., Stanley, F. J., Landau, L. I., Kendall, G. E., Oddy, W. H., Beilin, L. J. (2009). Synergy between adi- posity, insulin resistance, metabolic risk factors, and inflammation in adolescents. Diabetes Care, 32, 695-701.

Kershnar, A. K., Daniels, S. R., Imperatore, G., Palla, S. L., Petitti, D. B., Pettitt, D. J., Marcovina, S., Dolan, L. M., Hamman, R. F., Liese, A. D. Pihoker, C., Rodriguez, B. L. (2006). Lipid abnormalities are prevalent in youth with type 1 and type 2 diabetes: The SEARCH for Diabetes in Youth Study. J. Pediatr., 149, 314-319.

Maahs, D. M., Wadwa, R. P., Bishop, F., Daniels, S., R., Rewers, M., Klingensmith, G. J. (2008). Dyslipidemia in youth with diabetes: To treat or not to treat? J. Pediatr., 153, 458-465.

Speiser, P., W., Rudolf, M., C., J., Anhalt, H., Camacho-Hubner, C., Chiarelli, F., Eliakim, A., Freemark, M., Gruters, A., Hershkovitz, E., Iughetti, L., Krude, H., Latzer, Y., Lustig, R. H., Pescovitz, O. H., Pinhas-Hamiel, O., Rogol, A. D., Shalitin, S., Sultan, C., Stein, D., Vardi, P., Werther, G. A., Zadik, Z., Zuckerman-Levin, N., Hochberg, Z. (2005) Consensus statement: Childhood obesity. J. Clin. Endocrinol. Metab., 90, 1871-1887.

Pinhas-Hamiel, O., Zeitler, P. (2007). Acute and chronic complications of type 2 diabetes mellitus in children and adolescents. Lancet, 369, $1823-1831$.

Rodbard, H. W., Blonde, L., Braithwaite, S. S., Brett, E. M., Cobin, R. H., Handelsman, Y., Hellman, R., Jellinger, P. S., Jovanovic, L. G., Levy, P., Mechanick, J. I., Zangeneh, F.; AACE Diabetes Mellitus Clinical Practice Guidelines Task Force. (2007). American Association of Clinical Endocrinologists medical guidelines for clinical practice for the management of diabetes mellitus. Endocrin. Pract., 13 (Suppl 1), 1-68.

Rosenbloom, A. L., Silverstein, J. H., Amemiya, S., Zeitler, P., Klingensmith, G. J. (2008). Type 2 diabetes mellitus in the child and adolescents. Pediatric Diabetes, 9, 512-526.

Wiegand, S., Maikowski, U., Blankenstein, O., Biebermann, H., Tarnow, P., Grüters, A. (2004). Type 2 diabetes and impaired glucose tolerance in European children and adolescents with obesity: A problem that is no longer restricted to minority groups. Eur. J. Endocrinol., 151, 199-206.

Yoon, J. M. (2014). Dyslipidemia in children and adolescents: When and how to diagnose and treat? Pediatric Gastroenterol. Hepatol. Nutr., 17 (2), $85-92$

Önal, Z. E., Atasayan, V., Gürbüz, T., Hepkaya, E, Nuhošlu, C. (2014). Association of glycosylated hemoglobin (HbA1c) levels with insulin resistance in obese children. African Health Sci., 14, 533-538.

Štāle, M., Skrule, J. (2012). Latvijas iedzìvotāju veselība [Health of Latvian Population]. Slimību profilakses un kontroles centrs, Rīga. 112 lpp.

Received 13 September 2017

Accepted in the final form 3 May 2018

First published online 4 October 2018

\section{TIPA CUKURA DIABĒTS, GLIKOZES TOLERANCES TRAUCĒJUMI BĒRNIEM UN ASOCIĒTĀS BLAKUS SASLIMŠANAS BĒRNU KLĪNISKĀS UNIVERSITĀTES SLIMNĪCĀ LATVIJĀ, 2002-2013}

Pēdējo 20 gadu laikā pasaulē strauji pieaug saslimstība ar 2. tipa cukura diabētu bērniem. Saslimstības pieaugums tiek skaidrots ar neveselīgu paradumu izplatību, strauju aptaukošanās izplatību bērniem, it īpaši pusaudžiem, kā arī ar diagnostikas uzlabošanos. Galvenā saslimstības ar cukura diabētu problēma ir mikrovaskulāru un makrovaskulāru komplikāciju attīstība, kas ir par iemeslu agrīnai invaliditātei un priekšlaicīgai nāvei. Pētîjuma mērkis bija apzināt bērnu grupu ar 2. tipa cukura diabētu un glikozes tolerances traucējumiem un pētît asociētās blakus saslimšanas diagnozes noteikšanas brīdī Bērnu klīniskās universitātes slimnīcā Latvijā. No visām stacionāra pacientu slimības vēsturēm, kas ārstējušies laikā posmā no 2002. līdz 2013. gadam Bērnu endokrinoloǵijas centrā, tika retrospektīvi atlasītas pacientu slimības vēstures ar glikozes tolerances traucējumu vai 2. tipa cukura diabēta diagnozi. Iekḷaušanas kritērijiem atbilda 57 pacientu vēstures. $24(42 \%)$ pacientiem bija diagnosticēts 2. tipa cukura diabēts, bet $33(58 \%)$ pacientiem glikozes tolerances traucējumi. Visiem pētījuma bērniem, retrospektīvi izvērtējot ķermeṇa masas indeksu atbilstoši procentīlu līknēm pēc vecuma un dzimuma, bija konstatēts liekais svars. 2. tipa cukura diabēta bērnu grupā bija konstatēta aptaukošanās, jo kermenna masas indekss bija virs 99 . procentīles. Jau 2. tipa cukura diabēta diagnosticēšanas brīdī $54.2 \%$ bērnu bija konstatēta dislipidēmija un $66.7 \%$ — arteriālā hipertensija. 2. tipa cukura diabēts 71\% ( $\mathrm{n}=17)$ gadījumu bija diagnosticēts meitenēm. Statistiski nozīmīgi meitenēm ar 2. tipa cukura diabētu bija augstāks kopējais holesterīna līmenis $(p=0,02)$ un zema blīvuma lipoproteīna līmenis $(p=0,003)$. Nemot vērā, ka meitenēm ar 2. tipa cukura diabētu ir augsts risks sirds un asinsvadu slimībām pieaugušo vecumā, nepieciešams agrīni pievērst uzmanību ne tikai glikozes līmeņa normalizācijai, bet arī blakusslimību kontrolei, lai mazinātu turpmākas mikrovaskulāro un makrovaskulāro komplikāciju attīstības risku. 